\title{
Occupational Exposure to Polychlorinated Dibenzo-p-dioxins and Dibenzofurans, Dioxin-like Polychlorinated Biphenyls, and Polychlorinated Naphthalenes in Workplaces of Secondary Nonferrous Metallurgical Facilities in China
}

\author{
Jicheng Hu, Minghui Zheng,* Wenbin Liu, Changliang Li, Zhiqiang Nie, Guorui Liu, Ke Xiao, \\ and Shujun Dong
}

State Key Laboratory of Environmental Chemistry and Ecotoxicology, Research Center for Eco-Environmental Sciences, Chinese Academy of Sciences, P.O. Box 2871, Beijing 100085, China

\section{Supporting Information}

\begin{abstract}
The concentrations of polychlorinated dibenzo- $p$-dioxins and dibenzofurans (PCDD/Fs), dioxin-like polychlorinated biphenyls (dl-PCBs), and polychlorinated naphthalenes (PCNs) were determined in workplace air from eight secondary nonferrous metal processing plants to investigate occupational exposure to these toxic compounds. The total estimated daily intakes of PCDD/Fs and dlPCBs for workers by inhalation in the workplace were in the range of 0.15-9.91 and $0.13-8.59 \mathrm{pg}$ of WHO-TEQ/ $\mathrm{kg}$ of body weight (bw) for moderate and light activities, respectively. The daily inhalation doses for workers in the workplaces of three investigated plants exceeded the tolerable daily intake recommended by the World Health Organization. These results indicate that the risk of occupational exposure to dioxins by inhalation in the workplace of plants investigated was considerably high. For PCNs, the daily inhalation doses for workers in the workplace were in the range of $0.005-4.46$ and $0.004-3.87 \mathrm{pg}$ of TEQ/ $\mathrm{kg}$ of bw for moderate and light activities, respectively, which were lower than those of dioxins. To identify the source of PCDD/Fs, PCBs, and PCNs in workplace air, their homologue profiles were compared with those in stack gas from the plants investigated. It was found that significant dioxin contamination in workplace air was mainly attributed to the emission of fugitive gas from smelting furnaces during reclamation processes.

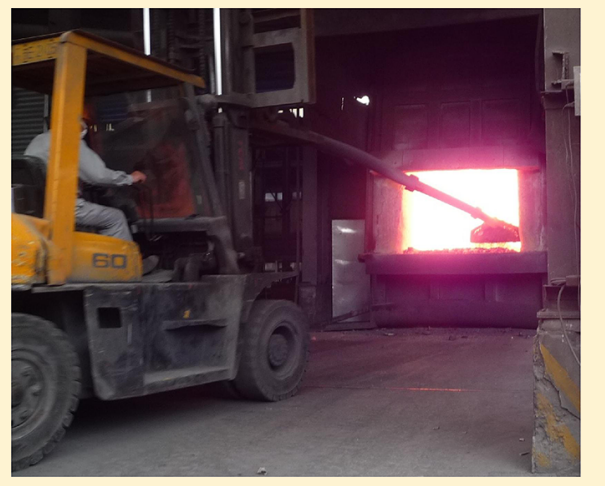

\section{INTRODUCTION}

Secondary metal smelters primarily engage in the recovery of nonferrous metals and alloys from new and used scrap and dross. Scrap metal and metal wastes may contain organic materials, such as plastics, paints, and solvents. ${ }^{1}$ High emissions of unintentionally produced persistent organic pollutants (UPPOPs) have been determined in stack gas of secondary nonferrous metal processing plants, caused by the combustion of these impurities in the presence of various types of metals during reclamation processes. ${ }^{2-6}$ During the secondary nonferrous metal smelting process, the smelting furnace door would be open for feeding raw material, mixing, and other necessary operations. Therefore, fugitive UP-POP emissions can be directly released into the workplace air during the process. Several studies have been conducted to investigate polychlorinated dibenzo- $p$-dioxin and dibenzofuran $(\mathrm{PCDD} / \mathrm{F})$ concentrations in the workplace air of some industrial thermal processes, such as sinter plants, municipal solid waste incinerators (MSWIs), and secondary aluminum and copper smelters. $^{7-10}$ Moreover, the results of these studies suggested that there was significant $\mathrm{PCDD} / \mathrm{F}$ contamination in the workplace air of the industrial thermal process plants investigated. Shih et al. ${ }^{8}$ investigated $\mathrm{PCDD} / \mathrm{F}$ levels in the workplace atmosphere of a sinter plant, and their results indicated that PCDD/F concentrations in workplace air (0.55$2.14 \mathrm{pg}$ of I-TEQ $/ \mathrm{m}^{3}$ ) were obviously higher than that of the outside ambient environment $\left(0.07 \mathrm{pg}\right.$ of $\left.\mathrm{I}-\mathrm{TEQ} / \mathrm{m}^{3}\right)$. In a secondary aluminum smelter, $\mathrm{PCDD} / \mathrm{F}$ concentrations during operation were observed to be higher than that during periods of no operation in workplace air. ${ }^{7}$ Relatively high concentrations of $\mathrm{PCDD} / \mathrm{Fs}$ were observed in the air samples collected near the furnace and casting department of a secondary copper smelter $\left(1.41-34.8 \mathrm{pg}\right.$ of WHO-TEQ $\left./ \mathrm{m}^{3}\right)$ and a secondary aluminum smelter $(0.49-12.6 \mathrm{pg}$ of WHO$\left.\mathrm{TEQ} / \mathrm{m}^{3}\right){ }^{9}$ Shih et al. ${ }^{10}$ found that PCDD/F WHO-TEQ concentrations in the workplace air were 5-15 times higher than those in the surrounding environment of two MSWIs. However, there is a lack of information about the concentrations of dioxins in the workplace air compared with intensive studies of dioxin emissions via stack gas from industrial thermal processes. ${ }^{2-4,11-13}$

Received: April 16, 2013

Revised: June 6, 2013

Accepted: June 11, 2013

Published: June 11, 2013 
Although remarkably high levels of $\mathrm{PCDD} / \mathrm{F}$ contamination have been observed in workplace air from secondary nonferrous metal processing plants in previous studies, ${ }^{7,9}$ few investigations of the assessment of occupational exposure to airborne PCDD/Fs at the workplaces have been conducted, not to mention polychlorinated biphenyls (PCBs) and polychlorinated naphthalenes (PCNs). Furthermore, $\mathrm{PCNs}$ have recently been proposed for inclusion in Annexes A, B, and/or C to the Stockholm Convention, 2011. Therefore, eight secondary nonferrous metal processing plants were investigated for the concentrations of UP-POPs (PCDD/Fs, dl-PCBs, and PCNs) in the workplace air in this study. The plants investigated include secondary copper smelters $(\mathrm{SeCu})$, secondary aluminum smelters (SeAl), and secondary lead smelters ( $\mathrm{SePb})$. A preliminary assessment was performed on occupational exposure to PCDD/Fs, dl-PCBs, and PCNs by inhalation in the workplace. In addition, UP-POPs in stack gas from these secondary nonferrous metal processing plants were also determined. The homologue profiles of UP-POPs in workplace air were compared with those in stack gas to identify the source of UP-POPs in workplace air. The results of this study will be helpful for understanding occupational exposure to UP-POPs by inhalation in workplaces of secondary nonferrous metallurgical facilities.

\section{MATERIALS AND METHODS}

Sampling. Eight typical secondary nonferrous metal processing plants were investigated, including $\mathrm{SeCu}, \mathrm{SeAl}$, and $\mathrm{SePb}$ (see the basic information in Table 1). Air samples

Table 1. Basic Information about the Investigated Secondary Nonferrous Metal Processing Plants

\begin{tabular}{|c|c|c|c|c|c|}
\hline & plant & $\begin{array}{l}\text { capacity per } \\
\text { year } \\
\text { (thousand } \\
\text { tons) }\end{array}$ & raw material $^{a}$ & fuel & $\begin{array}{l}\text { air pollution } \\
\text { control system }\end{array}$ \\
\hline \multirow[t]{3}{*}{$\mathrm{SeCu}$} & TY & 100 & $\begin{array}{l}\text { copper scrap, } \\
\text { blister copper, } \\
\text { and ACRE }\end{array}$ & heavy oil & - \\
\hline & $\mathrm{CX}$ & 10 & $\begin{array}{l}\text { copper-bearing } \\
\text { residues }\end{array}$ & heavy oil & bag filters \\
\hline & YD & 200 & $\begin{array}{l}\text { copper scrap, } \\
\text { blister copper, } \\
\text { and ACRE }\end{array}$ & heavy oil & bag filters \\
\hline \multirow[t]{4}{*}{$\mathrm{SeAl}$} & SC & 26 & aluminum scrap & $\begin{array}{l}\text { natural } \\
\text { gas }\end{array}$ & $\begin{array}{l}\text { cyclone and } \\
\text { bag filters }\end{array}$ \\
\hline & QY & 180 & aluminum scrap & $\begin{array}{l}\text { natural } \\
\text { gas }\end{array}$ & $\begin{array}{l}\text { electrostatic } \\
\text { precipitators }\end{array}$ \\
\hline & $\mathrm{HY}$ & 100 & $\begin{array}{l}\text { aluminum scrap } \\
\text { and aluminum } \\
\text { ingot }\end{array}$ & $\begin{array}{c}\text { natural } \\
\text { gas }\end{array}$ & bag filters \\
\hline & $\mathrm{TF}$ & 15 & aluminum scrap & $\begin{array}{l}\text { natural } \\
\text { gas }\end{array}$ & bag filters \\
\hline $\mathrm{SePb}$ & JA & 10 & $\begin{array}{l}\text { lead-bearing part } \\
\text { in plumbic } \\
\text { accumulator }\end{array}$ & $\begin{array}{c}\text { natural } \\
\text { gas }\end{array}$ & bag filters \\
\hline
\end{tabular}

$a_{\text {The raw material source was relatively stable, and there was no great }}$ variation in its composition. ${ }^{b}$ Anode copper remains after electrolysis.

from workplaces were collected using high-volume samplers (Echo Hi-Vol, Tecora Co.) in accordance with U.S. Environmental Protection Agency (EPA) Method TO-9A. Sampling points were located near the smelting furnace and on the side of the worker's operating platform, such as in the feed and mixing. Particulates were collected onto cleaned glass fiber filters (GFFs) (102 $\mathrm{mm}$ in diameter), whereas the gas phase was adsorbed onto polyurethane foam (PUF) (63 $\mathrm{mm}$ diameter and $76 \mathrm{~mm}$ length). Prior to the sampling, the GFFs were baked at $450{ }^{\circ} \mathrm{C}$ to remove organic contaminants, and the PUFs were Soxhlet-extracted with acetone for $12 \mathrm{~h}$. The air sampling flowing rate was $0.22 \mathrm{~m}^{3} / \mathrm{min}$, and each sample was collected continuously for approximately $24 \mathrm{~h}$ during the smelting process. The sampling period covered all smelting process and also covered all working hours over the three $8 \mathrm{~h}$ shifts. In addition, three stack gas samples were collected simultaneously from each plant by an automatic isokinetic sampling system, Isostack Basic (TCR Tecora), according to European Standard EN-1948. Once the stack gas and air sampling were completed, the samples were tightly wrapped in aluminum foil and packed in sealed polyethylene bags to prevent contamination and loss. They were then brought back to the laboratory and stored at $-18{ }^{\circ} \mathrm{C}$ until they were analyzed.

Sample Analysis. In this study, analysis of 17 2,3,7,8$\mathrm{PCDD} / \mathrm{F}$ and $12 \mathrm{dl}-\mathrm{PCB}$ congeners was conducted on the basis of modifications of U.S. EPA Methods 1613 and 1668A, respectively. Tri- to octachlorinated naphthalenes were analyzed by the isotope dilution high-resolution gas chromatography-high-resolution mass spectrometry (HRGCHRMS) method as described in our previous study. ${ }^{14}$ The samples were spiked with known amounts of ${ }^{13} \mathrm{C}_{12}$-labeled PCDD/F, ${ }^{13} \mathrm{C}_{12}$-labeled PCB, and ${ }^{13} \mathrm{C}_{10}$-labeled PCN internal standards (Table S1 of the Supporting Information) and then were Soxhlet-extracted with toluene for approximately $24 \mathrm{~h}$. Subsequently, the sample extracts were concentrated and subjected to a series of cleanups by adsorption chromatography, including an acid silica gel column, a multilayer silica gel column [from top to bottom, anhydrous sodium sulfate, $1 \mathrm{~g}$ of activated silica gel, $8 \mathrm{~g}$ of silica/ $\mathrm{H}_{2} \mathrm{SO}_{4} 44 \%(\mathrm{w} / \mathrm{w})$ gel, $1 \mathrm{~g}$ of activated silica gel, $5 \mathrm{~g}$ of silica/ $\mathrm{NaOH}(1 \mathrm{M}) 33 \%(\mathrm{w} / \mathrm{w})$ gel, 1 $\mathrm{g}$ of activated silica gel, $2 \mathrm{~g}$ of silica/ $/ \mathrm{AgNO}_{3} 10 \%(\mathrm{w} / \mathrm{w}) \mathrm{gel}$, and $1 \mathrm{~g}$ of activated silica gel], and a basic alumina column. Finally, the extracts were concentrated to approximately $20 \mu \mathrm{L}$ by rotary evaporation and a gentle nitrogen gas stream. Prior to injection, ${ }^{13} \mathrm{C}_{12}$-labeled $\mathrm{PCDD} / \mathrm{F},{ }^{13} \mathrm{C}_{12}$-labeled $\mathrm{PCB}$, and ${ }^{13} \mathrm{C}_{10}$-labeled PCN recovery standards (Table $\mathrm{S} 1$ of the Supporting Information) were added to the extracts. PCDD/ $\mathrm{F}$ and PCB analyses were performed by HRGC-HRMS with an Agilent 6890 gas chromatograph coupled to a Waters Autospec Ultima high-resolution mass spectrometer. A DB-5 $\mathrm{ms}$ capillary column $(60 \mathrm{~m} \times 0.25 \mathrm{~mm} \times 0.25 \mu \mathrm{m}$, Agilent $)$ was used. The high-resolution mass spectrometer was equipped with a positive electron impact (EI+) source. The selected ion monitoring analyzer mode was used with a resolving power of 10000. The electron energy and source temperature were specified at $35 \mathrm{eV}$ and $250{ }^{\circ} \mathrm{C}$, respectively. PCNs were analyzed using a Trace GC Ultra gas chromatograph coupled with a DFS mass spectrometer (Thermo Fisher Scientific) with an electron impact ion source. The high-resolution mass spectrometer was operated in selected ion monitoring mode with a resolution greater than 10000 . A DB-5 ms capillary column $(60 \mathrm{~m} \times 0.25 \mathrm{~mm} \times 0.25 \mu \mathrm{m}$, Agilent $)$ was also used for the separation of PCN congeners. The electron emission energy was set to $45 \mathrm{eV}$. The source temperature was $270{ }^{\circ} \mathrm{C}$.

The recoveries of $\mathrm{PCDD} / \mathrm{F}, \mathrm{PCB}$, and $\mathrm{PCN}$ internal standards were in the range of 50-120, 40-111, and 46$112 \%$ in the workplace air samples, respectively, and the recoveries were in the range of 40-117, 50-110, and 43-115\% in stack gas samples, respectively (Table S1 of the Supporting 
Table 2. Concentrations of UP-POPs in Workplace Air of the Plants Investigated (picograms per cubic meter)

\begin{tabular}{|c|c|c|c|c|c|c|c|c|}
\hline & & \multicolumn{2}{|c|}{$\mathrm{PCDD} / \mathrm{Fs}$} & \multicolumn{2}{|c|}{ PCBs } & \multirow[b]{2}{*}{$\sum \mathrm{TEQ}^{a}(\mathrm{PCDD} / \mathrm{Fs}$ and dl-PCBs $)$} & \multicolumn{2}{|c|}{$\mathrm{PCNs}^{b}$} \\
\hline & & $\sum 2378-\mathrm{PCDD} / \mathrm{Fs}$ & $\overline{\sum \mathrm{TEQ}^{a}}$ & $\sum \mathrm{dl}-\mathrm{PCBs}$ & $\overline{\sum \mathrm{TEQ}^{a}}$ & & $\sum \mathrm{PCNs}$ & $\overline{\sum T E Q}$ \\
\hline \multirow[t]{3}{*}{$\mathrm{SeCu}$} & TY & 800 & 44.5 & 279 & 5.07 & 49.6 & 4630 & 1.30 \\
\hline & $\mathrm{CX}$ & 1400 & 32.1 & 128 & 1.50 & 33.6 & 4530 & 1.13 \\
\hline & YD & 20.9 & 0.86 & 31.0 & 0.12 & 0.98 & 293 & 0.065 \\
\hline \multirow[t]{4}{*}{ SeAl } & SC & 556 & 26.0 & 726 & 0.96 & 27.0 & 31900 & 22.3 \\
\hline & QY & 5.28 & 0.52 & 569 & 0.21 & 0.73 & 1710 & 0.37 \\
\hline & HY & 13.3 & 1.75 & 32.5 & 0.21 & 1.96 & 640 & 0.26 \\
\hline & $\mathrm{TF}$ & 58.0 & 5.94 & 770 & 0.76 & 6.71 & 2510 & 0.081 \\
\hline $\mathrm{SePb}$ & JA & 12.7 & 0.78 & 15.5 & 0.070 & 0.85 & 252 & 0.026 \\
\hline
\end{tabular}

Information). In the identification of the target compounds, the following quality control criteria were used. (a) GC retention times were matched to the corresponding standard compounds. (b) A signal-to-noise ratio of $>3: 1$ was used. (c) The isotopic ratios between the quantitative and confirmation ions were within $\pm 15 \%$ of the theoretical values. One method blank was included in each batch of samples, which had been spiked with the same amount of internal standard as the samples. No target compounds were detected in the blank samples.

\section{RESULTS AND DISCUSSION}

Concentrations of UP-POPs in Workplace Air. The concentrations of $\mathrm{PCDD} / \mathrm{Fs}$ and dl-PCBs were determined in air samples collected from the workplaces of the eight secondary nonferrous metal processing plants investigated. TEQs of PCDD/Fs and dl-PCBs were calculated using World Health Organization (WHO) $1998 \mathrm{TEF}^{15}$ and are listed in Table 2. There was a large variation in PCDD/F and dl-PCB concentrations among different metallurgy processes and among different plants in the same metal category. The concentrations of PCDD/Fs ranged from 0.52 to $44.5 \mathrm{pg}$ of WHO-TEQ $/ \mathrm{m}^{3}$ among secondary nonferrous metal processing plants. Several studies have investigated PCDD/F levels in the workplace air of $\mathrm{SeCu}, \mathrm{SeAl}$, and other industrial thermal processes (Table 3). It can be seen that the PCDD/F concentrations of $\mathrm{SeCu}$ and $\mathrm{SeAl}$ in this study were in agreement with those found in $\mathrm{SeCu}$ and $\mathrm{SeAl}$ reported by Lee et al. ${ }^{9}$ and aluminum recyclers reported by Sweetman et al., ${ }^{16}$ but higher than those of other industrial thermal processes listed in Table $3 .^{8-10,17,18} \mathrm{PCDD} / \mathrm{F}$ concentrations of $\mathrm{SePb}$ in this study were in agreement with those of iron ore sinter, ${ }^{8}$ a basic oxygen steelmaking plant, ${ }^{18}$ electric arc furnaces, ${ }^{9}$ and MSWIs. ${ }^{10}$ For dl-PCBs, the concentrations were in the range of $0.070-5.07 \mathrm{pg}$ of $\mathrm{WHO}-\mathrm{TEQ} / \mathrm{m}^{3}$ in workplace air among secondary nonferrous metal processing plants. PCB levels have seldom been reported in workplace air of secondary nonferrous metal processing plants, to the best of our knowledge, although some studies have investigated atmospheric levels of PCBs in the surrounding environment of industrial thermal processes. $^{19,20}$ With regard to PCNs, the total concentrations (tri- to octachlorinated naphthalenes) were in the range of $252-31900 \mathrm{pg} / \mathrm{m}^{3}$ in workplace air among secondary nonferrous metal processing plants (Table 2). The dioxin-like toxicity of PCNs has been investigated in previous studies. ${ }^{21-23}$ The relative potency factors (RPFs) of individual PCN congeners to 2378-TCDD estimated in these studies have been used to evaluate the toxicity of PCNs. ${ }^{14,24,25}$ In this study, the TEQs of PCNs were defined by the sum of the products of the concentration of each congener multiplied by its RPF
Table 3. PCDD/F Concentrations in Workplace Air of Various Industrial Processes

\begin{tabular}{|c|c|c|c|c|}
\hline \multirow{2}{*}{$\begin{array}{l}\text { industrial thermal } \\
\text { process }\end{array}$} & \multicolumn{2}{|c|}{$\begin{array}{c}\sum 2378-\mathrm{PCDD} / \mathrm{Fs} \\
\left(\mathrm{pg} / \mathrm{m}^{3}\right)\end{array}$} & \multicolumn{2}{|c|}{$\sum$ TEQs $\left(\mathrm{pg} / \mathrm{m}^{3}\right)$} \\
\hline & range & mean & range & mean \\
\hline iron ore sinter ${ }^{8}$ & $7.61-23.2$ & 16.6 & $0.55-2.14^{a}$ & $1.48^{a}$ \\
\hline iron ore sinter ${ }^{18}$ & $-{ }^{b}$ & $-{ }^{b}$ & $0.12-5.93^{c, d}$ & $1.21^{c, d}$ \\
\hline $\begin{array}{l}\text { basic oxygen } \\
\text { steelmaking } \\
\text { plant }^{18}\end{array}$ & $-{ }^{b}$ & $-{ }^{b}$ & $0.13-2.03^{c, d}$ & $0.71^{c, d}$ \\
\hline electric arc furnace 9 & $-{ }^{b}$ & $-{ }^{b}$ & $1.61-2.01^{c}$ & $1.81^{c}$ \\
\hline electric arc furnace ${ }^{17}$ & $2.6-69.5$ & 24.5 & $0.26-8.34^{c}$ & $2.46^{c}$ \\
\hline MSWIs $^{10}$ & $0.541-77.6$ & 14.9 & $0.0307-4.73^{c}$ & $0.822^{c}$ \\
\hline $\mathrm{SeAl}^{7}$ & $-^{b}$ & 5.50 & $-{ }^{b}$ & $0.571^{a}$ \\
\hline $\mathrm{SeAl}^{9}$ & $-^{b}$ & $--^{b}$ & $0.49-12.6^{c}$ & $7.16^{c}$ \\
\hline$\underset{\text { recyclers }}{\text { aluminum }}$ & $-{ }^{b}$ & $-{ }^{b}$ & $2.0-72.7$ & 17.7 \\
\hline $\mathrm{SeCu}^{9}$ & $-{ }^{b}$ & $-{ }^{b}$ & $1.41-34.8^{c}$ & $12.4^{c}$ \\
\hline SeAl (this study) & $5.28-556$ & 158 & $0.52-26.0^{c}$ & $8.55^{c}$ \\
\hline $\mathrm{SeCu}$ (this study) & $20.9-1400$ & 741 & $0.86-44.5^{c}$ & $25.8^{c}$ \\
\hline $\mathrm{SePb}$ (this study) & 12.7 & & $0.78^{c}$ & \\
\hline
\end{tabular}

${ }^{a}$ Data were reported using I-TEF. ${ }^{b}$ Data were not reported. ${ }^{c}$ Data were reported using WHO1998-TEF. ${ }^{d}$ Data include WHO-12 PCB.

reported by Noma et al. ${ }^{24}$ (Table S2 of the Supporting Information). The dioxin-like PCNs (dl-PCNs) were defined as those congeners whose toxic equivalent factors have been calculated (Table S2 of the Supporting Information). The TEQ concentrations of PCNs were in the range of 0.026-22.3 pg/ $\mathrm{m}^{3}$ in workplace air among secondary nonferrous metal processing plants. There are no reports concerning PCN levels in workplace air from secondary nonferrous metal processing to the best of our knowledge.

To improve our understanding of UP-POP levels in workplace air from the plants investigated, UP-POP concentrations in this study were compared with those in ambient air reported in previous studies. Intensive studies of the atmospheric levels of $\mathrm{PCDD} / \mathrm{Fs}$ in local environments all over the world have been conducted. A review of PCDD/F concentrations in ambient air was presented by Lohmann and Jones; ${ }^{26}$ the general trend in TEQs is as follows: $<10 \mathrm{fg} / \mathrm{m}^{3}$ at remote sites, $20-50 \mathrm{fg} / \mathrm{m}^{3}$ at rural sites, and $100-400 \mathrm{fg} / \mathrm{m}^{3}$ at urban and industrial sites. Atmospheric levels of PCBs and PCNs have also been reported in many countries and regions, with concentrations in the range of $0.5-148 \mathrm{fg}$ of WHO-TEQ/ $\mathrm{m}^{3}$ for PCBs and $2-160 \mathrm{pg} / \mathrm{m}^{3}$ for PCNs. ${ }^{27-32}$ The concentrations of PCDD/Fs, PCBs, and PCNs in this study were obviously higher than the values mentioned above 
reported for ambient air. In addition, the total WHO-TEQ concentrations of PCDD/Fs and dl-PCBs (0.73-49.6 pg of $\left.\mathrm{TEQ} / \mathrm{m}^{3}\right)$ in workplace air in this study were all higher than the ambient air quality limitations for dioxins $\left(0.6 \mathrm{pg}\right.$ of TEQ $\left./ \mathrm{m}^{3}\right)$ in Japan. ${ }^{33}$ Furthermore, the TEQ concentrations of PCNs in workplace air from the TY, CX, and SC plants (1.30, 1.13, and $22.3 \mathrm{pg}$ of $\mathrm{TEQ} / \mathrm{m}^{3}$, respectively) were also higher than the concentration limits mentioned above. Therefore, workers were exposed to high concentrations of airborne PCDD/Fs, dlPCBs, and PCNs in the secondary nonferrous metal smelting processing plants investigated. It is essential that occupational exposure to these compounds be assessed to understand the potential exposure risk of workers in these workplaces.

Occupational Exposure to UP-POPs in the Workplace. Currently, occupational exposure to UP-POPs in the workplace is considered only in terms of inhalation via air; occupational exposure in managing highly contaminated fly ashes was ignored. Inhalation exposure to PCDD/Fs, dl-PCBs, and PCNs in the workplace was roughly estimated by assuming inhalation rates of 1.5 and $1.3 \mathrm{~m}^{3} / \mathrm{h}$ for moderate and light activities, respectively, ${ }^{17}$ and an $8 \mathrm{~h}$ work shift. The inhalation dose was calculated by the following equation:

$$
\mathrm{ID}=\left(C_{\text {air }} I_{\text {rate }} T_{\mathrm{w}} f_{\mathrm{r}}\right) / \mathrm{BW}
$$

where ID is inhalation dose for workers in the workplace in picograms of TEQ per kilogram of body weight per day, $C_{\text {air }}$ is air concentration expressed in picograms of TEQ per cubic meter, $I_{\text {rate }}$ is the inhalation rate of a worker in cubic meters per hour, $T_{\mathrm{w}}$ is the exposure time in the workplace (hours), $f_{\mathrm{r}}$ is inhalation absorption factor ( 1 was used assuming 100\% absorption $){ }^{16-18}$ and $\mathrm{BW}$ is the body weight of workers (60 $\mathrm{kg}$ ).

Table 4 lists the estimated daily intakes of PCDD/Fs, dlPCBs, and PCNs for workers by inhalation in the workplace. The total estimated daily intakes of PCDD/Fs and dl-PCBs for workers by inhalation in the workplace were in the range of $0.15-9.91$ and $0.13-8.59 \mathrm{pg}$ of WHO-TEQ $/ \mathrm{kg}$ of body weight for moderate and light activities, respectively. Preliminary health risk assessments were performed by comparison with the recommended tolerable daily intake (TDI). The WHO European Centre for Environment and Health recommended a TDI of $1-4 \mathrm{pg}$ of WHO-TEQ $/ \mathrm{kg}$ of body weight (including the WHO-12 PCBs) in 1998, ${ }^{34}$ while a TDI of 2 pg of WHO$\mathrm{TEQ} / \mathrm{kg}$ of body weight per day was recommended by the UK Committee on the Toxicity of Chemicals in Food, Consumer Products and the Environment (COT), based upon effects on the developing male reproductive system mediated via the maternal body burden. ${ }^{35}$ It can be observed that the estimated inhalation dose of dioxins (PCDD/Fs and dl-PCBs) in the workplace of TY, CX, and SC plants exceeded the TDI recommended by WHO and COT, although dietary intakes are not considered for workers. In previous studies, it was estimated that $>90 \%$ of exposure of the general population to these compounds occurs through diet, with food from animal origin being the predominant source. ${ }^{17,34,36}$ However, the daily intakes by inhalation for workers in the workplace in this study were already comparable with the TDI. Therefore, the results indicated that the risk of occupational exposure to PCDD/Fs and dl-PCBs by inhalation in the workplace of the secondary nonferrous metal processing plants investigated was considerably high.

Meanwhile, it is noteworthy that the estimated inhalation dose of PCNs in the workplace of SC plants had reached a
Table 4. Estimated Daily Intakes of UP-POPs for Workers in the Workplaces of Secondary Nonferrous Metal Processing Plants (picograms of TEQ per kilogram of body weight)

\begin{tabular}{|c|c|c|c|c|c|}
\hline & & $\mathrm{PCDD} / \mathrm{Fs}^{a}$ & $\mathrm{dl}-\mathrm{PCBs}{ }^{a}$ & $\begin{array}{l}\text { sum of } \mathrm{PCDD} / \mathrm{Fs} \\
\text { and dl-PCBs }{ }^{a}\end{array}$ & $\mathrm{PCNs}^{b}$ \\
\hline \multirow[t]{2}{*}{ TY } & light activity & 7.71 & 0.88 & 8.59 & 0.23 \\
\hline & $\begin{array}{c}\text { moderate } \\
\text { activity }\end{array}$ & 8.90 & 1.01 & 9.91 & 0.26 \\
\hline \multirow[t]{2}{*}{$\mathrm{CX}$} & light activity & 5.56 & 0.26 & 5.82 & 0.20 \\
\hline & $\begin{array}{l}\text { moderate } \\
\text { activity }\end{array}$ & 6.42 & 0.30 & 6.72 & 0.23 \\
\hline \multirow[t]{2}{*}{ YD } & light activity & 0.15 & 0.021 & 0.17 & 0.011 \\
\hline & $\begin{array}{l}\text { moderate } \\
\text { activity }\end{array}$ & 0.17 & 0.024 & 0.20 & 0.013 \\
\hline \multirow[t]{2}{*}{ SC } & light activity & 4.51 & 0.17 & 4.67 & 3.87 \\
\hline & $\begin{array}{l}\text { moderate } \\
\text { activity }\end{array}$ & 5.20 & 0.19 & 5.39 & 4.46 \\
\hline \multirow[t]{2}{*}{ QY } & light activity & 0.090 & 0.036 & 0.13 & 0.064 \\
\hline & $\begin{array}{c}\text { moderate } \\
\text { activity }\end{array}$ & 0.10 & 0.042 & 0.15 & 0.074 \\
\hline \multirow[t]{2}{*}{ HY } & light activity & 0.30 & 0.036 & 0.34 & 0.045 \\
\hline & $\begin{array}{c}\text { moderate } \\
\text { activity }\end{array}$ & 0.35 & 0.042 & 0.39 & 0.052 \\
\hline \multirow[t]{2}{*}{$\mathrm{TF}$} & light activity & 1.03 & 0.13 & 1.16 & 0.014 \\
\hline & $\begin{array}{c}\text { moderate } \\
\text { activity }\end{array}$ & 1.19 & 0.15 & 1.34 & 0.016 \\
\hline \multirow[t]{2}{*}{ JA } & light activity & 0.14 & 0.012 & 0.15 & 0.004 \\
\hline & $\begin{array}{c}\text { moderate } \\
\text { activity }\end{array}$ & 0.16 & 0.014 & 0.17 & 0.005 \\
\hline
\end{tabular}

${ }^{a}$ Data were calculated using WHO1998-TEQ. ${ }^{b}$ Data were calculated using TEQ of PCNs listed in Table 2.

relatively high level (4.46 and $3.87 \mathrm{pg}$ of TEQ/ $\mathrm{kg}$ of body weight for moderate and light activities, respectively). The estimated daily intakes by inhalation of $\mathrm{PCNs}$ were in the range of $0.005-0.26$ and $0.004-0.23 \mathrm{pg}$ of TEQ/ $\mathrm{kg}$ of body weight for moderate and light activities, respectively, in the workplaces of the other plants investigated. The assessment of inhalation exposure to PCNs for workers has not been reported in workplaces of secondary nonferrous metal processing plants to the best of our knowledge. These results suggested that more attention should be paid to the health risks of PCNs by inhalation in the workplace of secondary nonferrous metal processing plants.

To improve our understanding of the relative importance of PCNs compared with dioxins, the contribution of each compound (PCDD/Fs, dl-PCBs, and PCNs) to total UPPOP intake by inhalation was calculated for workers in the workplaces of plants investigated (Figure 1). The contribution of PCNs accounted for 45,34 , and $12 \%$ of the total UP-POP intake by inhalation in SC, QY, and HY plants, respectively. Moreover, the contribution of PCNs was comparable with that of PCDD/Fs in SC and QY plants (53 and 47\%, respectively). Park et al. ${ }^{37}$ found similar results among TEQ contributions of PCDD/Fs, PCBs, and PCNs in the serum of individuals working at MSWIs. In their study, the PCN contribution to total TEQ in the serum (26.8\%) was found to be slightly greater than that of the PCDDs (23.8\%), PCDFs (25.0\%), and PCBs $(24.3 \%) .{ }^{37}$ Nevertheless, the contributions of PCNs to total UP-POP intake by inhalation in TY, CX, YD, TF, and JA plants were relatively small (1.2-6.2\%). A possible difference in raw materials or operating conditions among different plants may be responsible for this difference and requires further research. With regard to the dl-PCBs, a relatively large contribution to total UP-POP intake by inhalation was found 


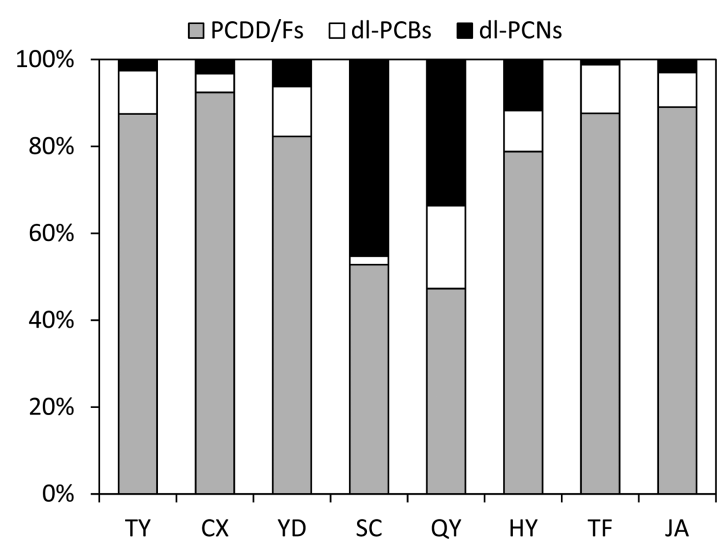

Figure 1. Contribution (percent) of each compound (PCDD/Fs, dlPCBs, and PCNs) to total UP-POP intake by inhalation in the workplace of the plants investigated.

in TY, YD, QY, and TF plants $(10,11,19$, and $11 \%$, respectively). The TEQ contribution from dl-PCBs formed via de novo synthesis usually accounted for approximately $3-7.5 \%$ of the total TEQ in the incineration processes. ${ }^{38,39}$ Therefore, other sources besides de novo formation may exist for the $\mathrm{dl}$ PCBs, such as industrial PCBs input via raw materials.

Source of UP-POPs in Workplace Air. UP-POP concentrations in stack gas also varied greatly among different metallurgies and among different plants in the same metal category (Table S3 of the Supporting Information). Upon comparison of UP-POP concentrations in workplace air with that in stack gas, similar trends were found for PCDD/Fs and dl-PCBs among the plants investigated (Figure 2). When a high concentration of UP-POPs was detected in stack gas, a relatively high concentration was also found in corresponding workplace air. For PCNs, a relatively high concentration was found in the workplace air sample of the SC plant. The trend of PCN concentrations between workplace air and stack gas was more similar when the SC plant was not included (Figure 2). UP-POP concentrations in stack gas can be affected by many factors, such as the raw materials, operating conditions, and air pollution control system (APCS). ${ }^{13,40}$ Fugitive gas is directly released into workplace air from a smelting furnace and was not influenced by an APCS. This may be why a relatively higher target compound concentration was detected among workplace air samples, whereas the concentrations were relatively low among stack gas samples in some plants. However, the similar trends of UP-POP concentrations suggested that the mechanism of formation of UP-POPs in the workplace air and stack gas should be similar.

To identify the source of UP-POPs in workplace air, homologue profiles were analyzed for tetra- to octa-CDD/Fs, tetra- to deca-CBs, and tri- to octa-CNs for PCDD/Fs, PCBs, and PCNs, respectively. As shown in Figure $S 1$ of the Supporting Information, higher chlorinated PCDFs were the main homologues in the TY, CX, YD, and SC plants, while lower chlorinated PCDFs were more abundant in the QY, HY, TF, and JA plants. For PCBs and PCNs, the main homologues were observed as lower chlorinated $\mathrm{CBs}$ and $\mathrm{CNs}$, and the weight distribution of $\mathrm{PCB}$ and $\mathrm{PCN}$ homologues decreased with an increasing degree of chlorination (Figures S2 and S3 of the Supporting Information). Furthermore, the UP-POP homologue profiles in workplace air were compared with those in stack gas (Figures S1-S3 of the Supporting Information). Although similar trends of UP-POP concentrations were found between workplace air and stack gas, it appears that there were certain differences for UP-POP homologue profiles. Overall, contributions of the higher chlorinated PCDD/Fs, PCBs, and PCNs in workplace air were higher than those in stack gas except for the TY plant.
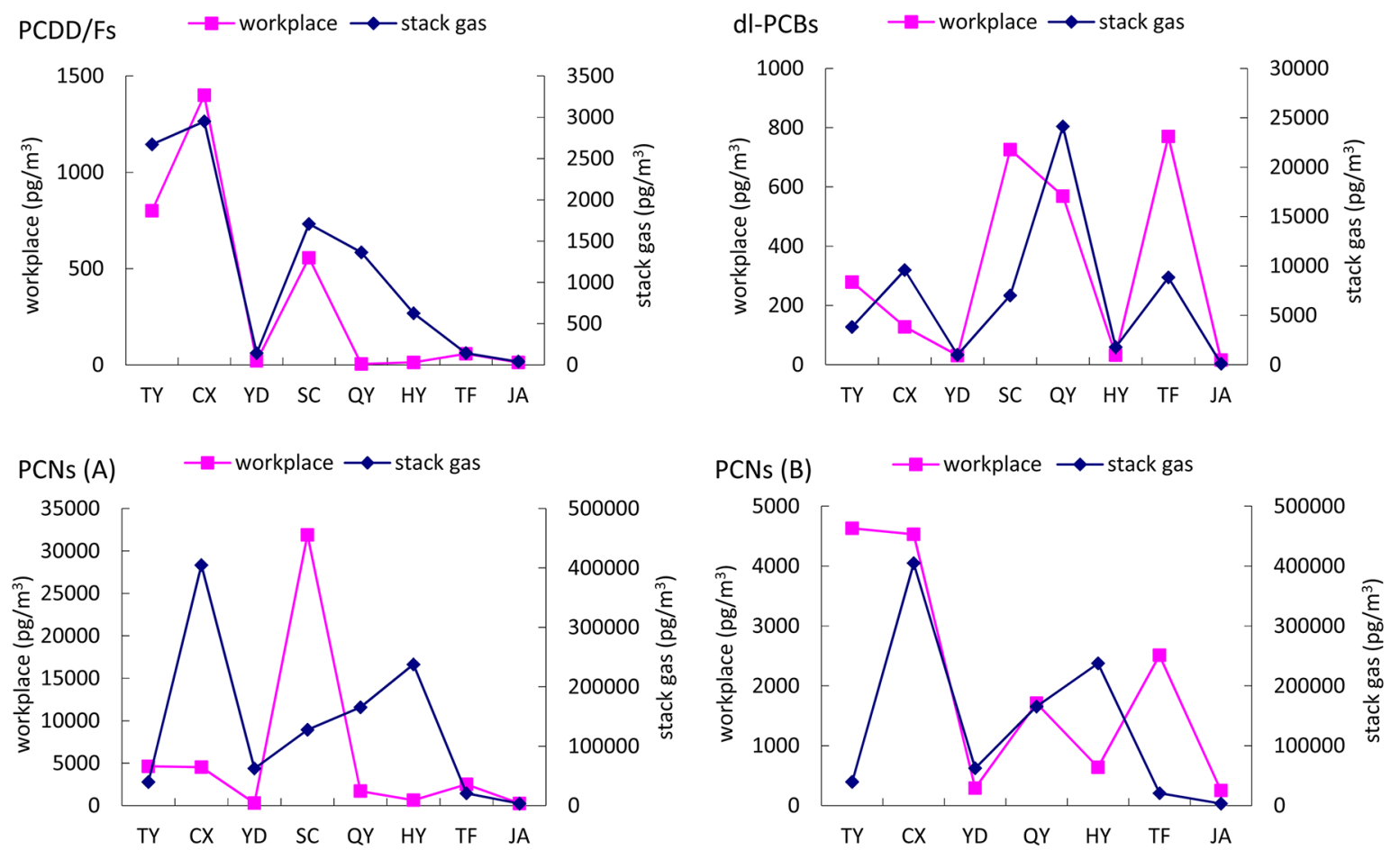

Figure 2. Comparison of UP-POP concentration trends between workplace air and stack gas from the plants investigated. $\mathrm{PCNs}(\mathrm{A})$ and $\mathrm{PCNs}(\mathrm{B})$ were the trends including and excluding the CS plant, respectively. 
Raw stack gas was sampled in the TY plant because no APCS was present. However, the particles in the stack gas, where the higher chlorinated homologues of PCDD/Fs, PCBs, and PCNs were more likely to bind, were removed effectively by APCSs in other plants (sampling points were set downstream of all APCSs). Moreover, as mentioned above, the fugitive gas was directly released into the workplace air from a smelting furnace and was not influenced by an APCS. As a result, the higher chlorinated homologues of PCDD/Fs, PCBs, and PCNs in workplace air appeared to be more abundant compared with that in stack gas. Obviously, this indicated that the significant UP-POP contamination in workplace air was mainly attributed to fugitive gas emission from smelting furnaces during the reclamation process. Therefore, secondary nonferrous metallurgical facilities should pay more attention to preventing the unintentional release of fugitive UP-POP emissions into workplace air from furnaces during the smelting process, along with effective control of their emissions via stack gas.

\section{ASSOCIATED CONTENT}

\section{S Supporting Information}

Additional information about recoveries of labeled standards for PCDD/Fs, PCBs, and PCNs; relative potency factors (RPFs) of the dl-PCN; UP-POP concentrations in stack gas of the plants investigated; $\mathrm{PCDD} / \mathrm{F}$ and $\mathrm{dl}-\mathrm{PCB}$ concentrations in workplace air of the plants investigated; and homologue profiles of UP-POPs in workplace air and stack gas from the plants investigated. This material is available free of charge via the Internet at http://pubs.acs.org.

\section{AUTHOR INFORMATION}

\section{Corresponding Author}

*Phone: +86 10 62849172. Fax: +86 10 62923563. E-mail: zhengmh@rcees.ac.cn.

Notes

The authors declare no competing financial interest.

\section{ACKNOWLEDGMENTS}

This study was supported by the National Natural Science Foundation of China (21037003) and the National 973 Program (2009CB421606).

\section{REFERENCES}

(1) An inventory of sources and environmental releases of dioxin-like compounds in the United States for the years 1987, 1995, and 2000; National Center for Environmental Assessment, Office of Research and Development, U.S. Environmental Protection Agency: Washington, DC, 2006 (http://www.epa.gov/ncea/pdfs/dioxin/2006/ dioxin.pdf).

(2) Ba, T.; Zheng, M.; Zhang, B.; Liu, W.; Su, G.; Liu, G.; Xiao, K. Estimation and congener-specific characterization of polychlorinated naphthalene emissions from secondary nonferrous metallurgical facilities in China. Environ. Sci. Technol. 2010, 44 (7), 2441-2446.

(3) Ba, T.; Zheng, M.; Zhang, B.; Liu, W.; Su, G.; Xiao, K. Estimation and characterization of PCDD/Fs and dioxin-like PCB emission from secondary zinc and lead metallurgies in China. J. Environ. Monit. 2009, 11 (4), 867-872.

(4) Ba, T.; Zheng, M.; Zhang, B.; Liu, W.; Xiao, K.; Zhang, L. Estimation and characterization of $\mathrm{PCDD} / \mathrm{Fs}$ and dioxin-like $\mathrm{PCBs}$ from secondary copper and aluminum metallurgies in China. Chemosphere 2009, 75 (9), 1173-1178.

(5) Yu, B. W.; Jin, G. Z.; Moon, Y. H.; Kim, M. K.; Kyoung, J. D.; Chang, Y. S. Emission of PCDD/Fs and dioxin-like PCBs from metallurgy industries in S. Korea. Chemosphere 2006, 62 (3), 494-501.
(6) Weber, R.; Gaus, C.; Tysklind, M.; Johnston, P.; Forter, M.; Hollert, H.; Heinisch, E.; Holoubek, I.; Lloyd-Smith, M.; Masunaga, S.; Moccarelli, P.; Santillo, D.; Seike, N.; Symons, R.; Torres, J. P. M.; Verta, M.; Varbelow, G.; Vijgen, J.; Watson, A.; Costner, P.; Woelz, J.; Wycisk, P.; Zennegg, M. Dioxin- and POP-contaminated sitescontemporary and future relevance and challenges. Environ. Sci. Pollut. Res. 2008, 15 (5), 363-393.

(7) Chen, S. J.; Lee, W. S.; Chang-Chien, G. P.; Wang, L. C.; Lee, W. J.; Kao, J. H.; Hu, M. T. Characterizing polychlorinated dibenzo-pdioxins and dibenzofurans in the surrounding environment and workplace of a secondary aluminum smelter. Atmos. Environ. 2004, 38 (22), 3729-3732.

(8) Shih, M.; Lee, W.-J.; Shih, T.-S.; Huang, S.-L.; Chang-Chien, G.P.; Wang, L.-C.; Tsai, P.-J. Characterization of dibenzo-p-dioxins and dibenzofurans $(\mathrm{PCDD} / \mathrm{Fs})$ in the atmosphere of a sinter of different workplaces plant. Sci. Total Environ. 2006, 366 (1), 197-205.

(9) Lee, C. C.; Shih, T. S.; Chen, H. L. Distribution of air and serum $\mathrm{PCDD} / \mathrm{F}$ levels of electric arc furnaces and secondary aluminum and copper smelters. J. Hazard. Mater. 2009, 172 (2-3), 1351-1356.

(10) Shih, S.-I.; Wang, Y.-F.; Chang, J.-E.; Jang, J.-S.; Kuo, F.-L.; Wang, L.-C.; Chang-Chien, G.-P. Comparisons of levels of polychlorinated dibenzo-p-dioxins/dibenzofurans in the surrounding environment and workplace of two municipal solid waste incinerators. J. Hazard. Mater. 2006, 137 (3), 1817-1830.

(11) Ni, Y.; Zhang, H.; Fan, S.; Zhang, X.; Zhang, Q.; Chen, J. Emissions of $\mathrm{PCDD} / \mathrm{Fs}$ from municipal solid waste incinerators in China. Chemosphere 2009, 75 (9), 1153-1158.

(12) Grochowalski, A.; Lassen, C.; Holtzer, M.; Sadowski, M.; Hudyma, T. Determination of PCDDs, PCDFs, PCBs and HCB emissions from the metallurgical sector in Poland. Environ. Sci. Pollut. Res. 2007, 14 (5), 326-332.

(13) Wyrzykowska-Ceradini, B.; Gullett, B. K.; Tabor, D.; Touati, A. PBDDs/Fs and PCDDs/Fs in the raw and clean flue gas during steady state and transient operation of a municipal waste combustor. Environ. Sci. Technol. 2011, 45 (13), 5853-5860.

(14) Guo, L.; Zhang, B.; Xiao, K.; Zhang, Q.; Zheng, M. Levels and distributions of polychlorinated naphthalenes in sewage sludge of urban wastewater treatment plants. Chin. Sci. Bull. 2008, 53 (4), 508513.

(15) Van den Berg, M.; Birnbaum, L.; Bosveld, A. T. C.; Brunstrom, B.; Cook, P.; Feeley, M.; Giesy, J. P.; Hanberg, A.; Hasegawa, R.; Kennedy, S. W.; Kubiak, T.; Larsen, J. C.; van Leeuwen, F. X. R.; Liem, A. K. D.; Nolt, C.; Peterson, R. E.; Poellinger, L.; Safe, S.; Schrenk, D.; Tillitt, D.; Tysklind, M.; Younes, M.; Waern, F.; Zacharewski, T. Toxic equivalency factors (TEFs) for PCBs, PCDDs, PCDFs for humans and wildlife. Environ. Health Perspect. 1998, 106 (12), 775-792.

(16) Sweetman, A.; Keen, C.; Healy, J.; Ball, E.; Davy, C. Occupational exposure to dioxins at UK worksites. Ann. Occup. Hyg. 2004, 48 (5), 425-437.

(17) Aries, E.; Anderson, D. R.; Fisher, R. Exposure assessment of workers to airborne $\mathrm{PCDD} / \mathrm{Fs}, \mathrm{PCBs}$ and $\mathrm{PAHs}$ at an electric arc furnace steelmaking plant in the UK. Ann. Occup. Hyg. 2008, 52 (4), $213-225$.

(18) Jackson, K.; Aries, E.; Fisher, R.; Anderson, D. R.; Parris, A. Assessment of exposure to PCDD/F, PCB, and PAH at a basic oxygen steelmaking (BOS) and an iron ore sintering plant in the UK. Ann. Occup. Hyg. 2012, 56 (1), 37-48.

(19) Wang, M.-S.; Chen, S.-J.; Huang, K.-L.; Lai, Y.-C.; Chang-Chien, G.-P.; Tsai, J.-H.; Lin, W.-Y.; Chang, K.-C.; Lee, J.-T. Determination of levels of persistent organic pollutants (PCDD/Fs, PBDD/Fs, PBDEs, $\mathrm{PCBs}$, and $\mathrm{PBBs}$ ) in atmosphere near a municipal solid waste incinerator. Chemosphere 2010, 80 (10), 1220-1226.

(20) Li, X.; Li, Y.; Zhang, Q.; Wang, P.; Yang, H.; Jiang, G.; Wei, F. Evaluation of atmospheric sources of $\mathrm{PCDD} / \mathrm{Fs}$, PCBs and PBDEs around a steel industrial complex in northeast China using passive air samplers. Chemosphere 2011, 84 (7), 957-963.

(21) Blankenship, A. L.; Kannan, K.; Villalobos, S. A.; Villeneuve, D. L.; Falandysz, J.; Imagawa, T.; Jakobsson, E.; Giesy, J. P. Relative potencies of individual polychlorinated naphthalenes and halowax 
mixtures to induce Ah receptor-mediated responses. Environ. Sci. Technol. 2000, 34 (15), 3153-3158.

(22) Hanberg, A.; Waern, F.; Asplund, L.; Haglund, E.; Safe, S. Swedish dioxin survey: Determination of 2,3,7,8-TCDD toxic equivalent factors for some polychlorinated-biphenyls and naphthalenes using biological tests. Chemosphere 1990, 20 (7-9), 1161-1164.

(23) Villeneuve, D. L.; Kannan, K.; Khim, J. S.; Falandysz, J.; Nikiforov, V. A.; Blankenship, A. L.; Giesy, J. P. Relative potencies of individual polychlorinated naphthalenes to induce dioxin-like responses in fish and mammalian in vitro bioassays. Arch. Environ. Contam. Toxicol. 2000, 39 (3), 273-281.

(24) Noma, Y.; Yamamoto, T.; Sakai, S. I. Congener-specific composition of polychlorinated naphthalenes, coplanar PCBs, dibenzo-p-dioxins, and dibenzofurans in the halowax series. Environ. Sci. Technol. 2004, 38 (6), 1675-1680.

(25) Liu, G.; Zheng, M.; Liu, W.; Wang, C.; Zhang, B.; Gao, L.; Su, G.; Xiao, K.; Lv, P. Atmospheric emission of PCDD/Fs, PCBs, hexachlorobenzene, and pentachlorobenzene from the coking industry. Environ. Sci. Technol. 2009, 43 (24), 9196-9201.

(26) Lohmann, R.; Jones, K. C. Dioxins and furans in air and deposition: A review of levels, behaviour and processes. Sci. Total Environ. 1998, 219 (1), 53-81.

(27) Moussaoui, Y.; Tuduri, L.; Kerchich, Y.; Meklati, B. Y.; Eppe, G. Atmospheric concentrations of PCDD/Fs, dl-PCBs and some pesticides in northern Algeria using passive air sampling. Chemosphere 2012, 88 (3), 270-277.

(28) Shin, S. K.; Jin, G. Z.; Kim, W. I.; Kim, B. H.; Hwang, S. M.; Hong, J. P.; Park, J. S. Nationwide monitoring of atmospheric PCDD/ Fs and dioxin-like PCBs in South Korea. Chemosphere 2011, 83 (10), 1339-1344.

(29) Cleverly, D.; Ferrario, J.; Byrne, C.; Riggs, K.; Joseph, D.; Hartford, P. A general indication of the contemporary background levels of PCDDs, PCDFs, and coplanar PCBs in the ambient air over rural and remote areas of the United States. Environ. Sci. Technol. 2007, 41 (5), 1537-1544.

(30) Hogarh, J. N.; Seike, N.; Kobara, Y.; Masunaga, S. Atmospheric polychlorinated naphthalenes in Ghana. Environ. Sci. Technol. 2012, 46 (5), 2600-2606.

(31) Hogarh, J. N.; Seike, N.; Kobara, Y.; Habib, A.; Jae-Jak, N.; Lee, J.-S.; Li, Q.; Liu, X.; Li, J.; Zhang, G.; Masunaga, S. Passive air monitoring of $\mathrm{PCBs}$ and $\mathrm{PCNs}$ across East Asia: A comprehensive congener evaluation for source characterization. Chemosphere 2012, 86 (7), 718-726.

(32) Choi, M. P. K.; Ho, S. K. M.; So, B. K. L.; Cai, Z.; Lau, A. K. H.; Wong, M. H. PCDD/F and dioxin-like PCB in Hong Kong air in relation to their regional transport in the Pearl River Delta region. Chemosphere 2008, 71 (2), 211-218.

(33) Information Brochure Dioxins; Office of Dioxins Control, Environmental Management Bureau, Ministry of the Environment, Government of Japan: Tokyo, 2009 (http://www.env.go.jp/en/ chemi/dioxins/brochure2009.pdf).

(34) EXECUTIVE SUMMARY: Assessment of the health risk of dioxins: Reevaluation of the tolerable daily intake (TDI); WHO consultation; WHO European Centre for Environment and Health International Programme on Chemical Safety: Geneva, 1998 (http:// www.who.int/ipcs/publications/en/exe-sum-final.pdf).

(35) Statement on the tolerable daily intake for dioxins and dioxinlike polychlorinated biphenyls; Committee on Toxicity (COT), Food Standards Agency: London, 2001 (http://www.cot.food.gov.uk/pdfs/ cot-diox-full.pdf).

(36) Li, Y.; Wang, P.; Ding, L.; Li, X.; Wang, T.; Zhang, Q.; Yang, H.; Jiang, G.; Wei, F. Atmospheric distribution of polychlorinated dibenzop-dioxins, dibenzofurans and dioxin-like polychlorinated biphenyls around a steel plant Area, Northeast China. Chemosphere 2010, 79 (3), 253-258.

(37) Park, H.; Kang, J.-H.; Baek, S.-Y.; Chang, Y.-S. Relative importance of polychlorinated naphthalenes compared to dioxins, and polychlorinated biphenyls in human serum from Korea: Contribution to TEQs and potential sources. Environ. Pollut. 2010, 158 (5), 14201427.

(38) Sakurai, T.; Weber, R.; Ueno, S.; Nishino, J.; Tanaka, M. Relevance of coplanar PCBs for TEQ emission of fluidized bed incineration and impact of emission control devices. Chemosphere 2003, 53 (6), 619-625.

(39) Sakai, S.; Ukai, T.; Takatsuki, H.; Nakamura, K.; Kinoshita, S.; Takasuga, T. Substance flow analysis of coplanar PCBs released from waste incineration processes. J. Mater. Cycles Waste Manage. 1999, 1 (1), 62-74.

(40) Stanmore, B. R. The formation of dioxins in combustion systems. Combust. Flame 2004, 136 (3), 398-427. 